\title{
PERILAKU BERBAGI PENGETAHUAN AKUNTANSI PADA DOSEN AKUNTANSI KOTA BENGKULU: PENDEKATAN THEORY OF PLANNED BEHAVIOR (TPB)
}

\author{
Madani Hatta ${ }^{1)}$, Baihaqi $^{2)}$, Resti Ramahdaniati ${ }^{3)}$ \\ Universitas Bengkulu \\ 1)madani.unib2006@gmail.com
}

\begin{abstract}
This study aims to determine the accounting knowledge sharing behavior at accounting lecturer in Bengkulu city, using the model theory of planned behavior influenced by three factor is attitude toward behavior, subjective norm, and perceived behavior control. Attitude toward behavior is influenced by factor self efficacy, social network, and extrinsic reward. While subjective norm is influenced by organization support. The population in this study were all accounting lecturer who worked in public and private universities in the city of Bengkulu using purposive sampling technique, so that the total sample of 62 people and data that can be used in this study were 43 respondents. Analysis technique using the assistance program smartPLS version 3 2.3. The results showed that self efficacy has positive affect on attitude toward behavior, social network has positive affect on attitude toward behavior, extrinsic reward has positive affect on attitude toward behavior, organizational support has positive affect on subjective norm, attitude toward behavior has positive affect on the accounting knowledege sharing behavior, subjective norm has positive affect on the accounting knowledege sharing behavior, and perceived behavior control has positive affect on the accounting knowledege sharing behavior.
\end{abstract}

Keywords: Theory of Planned Behavior, Attitude toward Behavior, Subjective Norm, Perceived Behavior Control

\begin{abstract}
Abstrak
Penelitian ini bertujuan untuk mengetahui perilaku berbagi pengetahuan akuntansi pada dosen akuntansi kota Bengkulu, menggunakan model theory of planned behavior (TPB) yang dipengaruhi oleh tiga faktor sikap terhadap perilaku, norma subjektif, dan perceived behavior control. Sikap terhadap perilaku dipengaruhi oleh faktor self efficacy, jaringan sosial, dan extrinsic reward, sedangkan norma subjektif dipengaruhi oleh dukungan organisasi. Populasi dalam penelitian ini adalah seluruh dosen akuntansi yang bekerja di perguruan tinggi negeri maupun swasta yang ada di Kota Bengkulu dengan menggunakan teknik purposive sampling, sehingga total sampel penelitian sebanyak 62 orang dan data yang dapat digunakan dalam penelitian ini adalah 43 responden Teknik analisa menggunakan bantuan program smartPLS versi 32.3 . Hasil penelitian menunjukkan bahwa self efficacy berpengaruh positif terhadap sikap terhadap perilaku, jaringan sosial berpengaruh positif terhadap sikap terhadap perilaku, extrinsic reward berpengaruh positif terhadap sikap terhadap perilaku, dukungan organisasi berpengaruh positif terhadap norma subjektif, sikap terhadap perilaku berpengaruh positif terhadap perilaku berbagi pengetahuan akuntansi, norma subjektif berpengaruh positif terhadap perilaku berbagi pengetahuan akuntansi, perceived behavior control berpengaruh positif terhadap perilaku berbagi pengetahuan akuntansi.
\end{abstract}

Kata Kunci: Theory of Planned Behavior (TPB), Sikap terhadap Perilaku, Norma Subjektif, Perceived Behavior Control 


\section{Pendahuluan}

Profesi bidang akuntansi mengalami perkembangan yang pesat seiring dengan perkembangan dunia bisnis dan sector publik. Salah satu yang dapat mengembangkan profesi akuntan tersebut adalah sektor pendidikan melalui lembaga pendidikan seperti perguruan tinggi. Akuntan pendidik merupakan salah satu profesi yang dapat mengembangkan profesi akuntan, agar dapat menciptakan lulusan akuntan yang terampil dan profesional, yang bertugas dalam pendidikan akuntansi, melakukan penelitian dan pengembangan akuntansi, mengajar, dan menyusun kurikulum pendidikan akuntansi di perguruan tinggi (IAI Global 2016), hal ini sesuai dengan Tri Dharma Perguruan Tinggi yang dilakukan oleh seorang dosen atau akuntan pendidik adalah melakukan kegiatan pendidikan dan pengajaran, penelitian dan pengembangan serta pengabdian masyarakat.

Selain untuk meningkatkan pendidikan, peningkatan kemampuan dan pengetahuan dapat dilakukan oleh dosen itu sendiri dengan cara berbagi pengetahuan, misalnya melalui kegiatan diskusi, seminar, pelatihan, dan lainnya. Menurut Saad dan Haron (2013), dosen yang saling berbagi pengetahuan dapat mengembangkan potensi yang ada didalam diri dosen tersebut menjadi lebih bermanfaat, meningkatkan kinerja dan produktifitasnya. Selain itu dosen yang dapat bekerja sama dan berkolaborasi dengan dosen maupun rekan kerja lain akan meningkatkan kualitas dari penelitian yang dilakukan serta memberikan kontribusi pada perkembangan pengetahuan (Kidwell et al., 2000).

Pada perguruan tinggi di Kota Bengkulu, kegiatan berbagi pengetahuan untuk dosen akuntansi dilakukan oleh Ikatan Akuntan Indonesia Wilayah Bengkulu. Selain itu beberapa perguruan tinggi negeri dan swasta di kota Bengkulu sering melakukan kegiatan seminar akuntansi dengan mengundang pemateri dosen dari perguruan tinggi di luar Bengkulu untuk menjadi pembicara di seminar tersebut, hal ini tentunya akan mendapatkan pengetahuan yang lebih seputaran akuntansi.

Menurut Ismail et al. (2009) berbagi pengetahuan sebagai pertukaran ide, pengalaman dan pemikiran di antara individu. Kegiatan berbagi pengetahuan akuntansi antar dosen akuntansi ini merupakan sebuah perilaku yang sangat bermanfaat, karena bagi dosen berbagi pengetahuan merupakan suatu hal yang akan mendapatkan nilai positif dari dalam diri, dan akan mempengaruhinya untuk menampilkan perilaku berbagi pengetahuan.

Theory of Planned Behavior (TPB) merupakan sebuah teori yang dapat menilai perilaku seseorang berdasarkan faktor dari TPB. Ketika individu melakukan kegiatan berbagi pengetahuan hal ini merupakan sebuah perilaku, sebagaimana didalam TPB perilaku dipengaruhi oleh niat, sedangkan niat dipengaruhi oleh beberapa faktor yaitu sikap terhadap perilaku (attitude toward behavior), norma subjektif (subjective norm), dan kontrol perilaku yang dipersepsikan (perceived behavior control).

Attitude toward behavior dibentuk dari kumpulan keyakinan seseorang (beliefs) tentang suatu perilaku (Ajzen, 1991). Attitude toward behavior merupakan persepsi dari seseorang yang berkeyakinan bahwa ketika individu melakukan suatu perilaku akan muncul sikap perasaan positif atau negatif yang akan mempengaruhinya untuk berperilaku. Dosen akan beranggapan bahwa berbagi pengetahuan merupakan suatu hal yang bermanfaaat karena akan mendapatkan nilai positif dari dalam diri dan memiliki sikap perasaan senang dan suka ketika dia berbagi pengetahuan, dari anggapan tersebut akan muncul sebuah perilaku berbagi pengetahuan, hal ini yang akan menghasilkan perilaku positif individu. Pada penelitian Jolaee et al. (2013) menunjukkan bahwa attitude toward behavior berpengaruh positif terhadap perilaku berbagi pengetahuan.

Selain attitude toward behavior, faktor lain yang dapat mempengaruhi perilaku seseorang ialah norma subjektif, menurut Ajzen (1991) norma subjektif adalah 
persepsi individu terhadap tekanan sosial yang dirasakan untuk melakukan atau tidak melakukan suatu perilaku. Seseorang akan beranggapan bahwa adanya sebuah dukungan dari orang-orang terdekat yang dirasakan untuk terlibat dalam suatu perilaku berbagi pengetahuan, dari perasaan tersebutlah akan muncul sebuah perilaku yang positif yang akan mempengaruhi dirinya untuk melakukan perilaku berbagi pengetahuan. Pada penelitian Jolaee et al. (2013) menunjukkan bahwa norma subjektif berpengaruh positif terhadap perilaku berbagi pengetahuan, semakin tinggi tekanan sosial yang dirasakan semakin tinggi juga perilaku seseorang yang akan ditampilkan.

Faktor terakhir yang mempengaruhi perilaku individu untuk berbagi pengetahuan adalah Perceived Behavior Control (PBC). PBC menurut Ajzen (1991) adalah persepsi kemudahan atau kesulitan individu untuk melakukan suatu perilaku yang diasumsikan untuk mencerminkan pengalaman masa lalu serta antisipasi terhadap hambatan dan rintangan. Seseorang akan berkeyakinan bahwa pengalaman terhadap suatu perilaku dipengaruhi oleh informasi yang didapat oleh orang lain, dari sebuah informasi tersebut dapat menjadi suatu pertimbangan untuk melakukan suatu perilaku. Ketika seorang dosen yakin bahwa ia dapat terlibat dalam perilaku berbagi pengetahuan dengan relatif mudah dan sedikit kendala, maka akan memiliki dampak positif terhadap perilakunya. Semakin tinggi persepsi suatu kemudahan terhadap perilaku berbagi pengetahuan maka semakin tinggi pula perilaku yang akan ditampilkan.

Selain beberapa faktor TPB yang mempengaruhi perilaku berbagi pengetahuan, penelitian Jolaee et al. (2013) telah menguji faktor yang mempengaruhi attitude toward behavior yaitu self eficacy, jaringan sosial, dan extrinsic reward, sedangkan faktor yang mempengaruhi norma subjektif adalah dukungan organisasi.
Self eficacy merupakan penilaian individu terhadap kemampuan dan kompetensinya untuk melakukan suatu tugas, mencapai suatu tujuan, dan menghasilkan sesuatu (Baron dan Byrne, 2000). Seorang dosen akan merasa bahwa dengan kemampuannya dapat mengatasi suatu situasi dan akan menghasilkan hal yang positif ketika ia berbagi pengetahuan dengan keyakinannya bahwa ia mampu mencapai suatu tujuan tertentu dengan berbagi pengetahuan. Pada penelitian Jolaee et al. (2013) menunjukkan bahwa semakin tinggi self efficacy seseorang maka semakin tinggi juga attitude toward behavior.

Jaringan sosial juga merupakan salah satu faktor yang mempengaruhi attitude toward behavior, disamping self efficacy. Jaringan sosial merupakan wadah para dosen akuntansi untuk berbagi pengetahuan seperti organisasi, komunitas dan asosiasi, misalnya saja asosiasi profesi akuntan seperti IAI. Seorang dosen akan beranggapan bahwa dengan adanya suatu jaringan sosial, saling berbagi pengetahuan dan pengalaman dan informasi seputaran akuntansi akan banyak didapatkan, hal inilah yang akan mempengaruhi attitude toward behavior dengan adanya suatu jaringan sosial. Semakin tinggi jaringan sosial yang dimiliki seseorang maka semakin tinggi juga attitude toward behavior.

Extrinsic reward merupakan sebuah penghargaan atau imbalan yang akan diterima ketika berbagi pengetahuan, extrinsic reward akan mempengaruhi dosen untuk berbagi pengetahuan akuntansi karena adanya sebuah penghargaan atau imbalan yang didapat berupa insentif, dana hibah pengabdian masyarakat, promosi jabatan, dan profit sharing, hal inilah yang dapat mempengaruhi attitude toward behavior. Semakin tinggi extrinsic reward yang didapatkan seseorang maka semakin tinggi juga attitude toward behavior untuk berbagi pengetahuan. 
Selain terdapat faktor-faktor yang mempengaruhi attitude toward behavior, terdapat juga faktor yang mempengaruhi norma subjektif, yaitu dukungan organisasi. Dukungan organisasi disini merupakan sebuah institusi tempat dosen bekerja yaitu perguruan tinggi, dengan adanya sebuah dukungan dari pihak perguruan tinggi seperti teknologi informasi pendukung, forum-forum dosen, fasilitas berupa dana, bantuan kegiatan dan lainnya akan mempengaruhi dukungan kepercayaan seorang dosen akuntansi terhadap perilaku berbagi pengetahuan akuntansi. Pada penelitian Jolaee et al. (2013) menunjukkan bahwa semakin tinggi dukungan organisasi seseorang maka semakin tinggi juga norma subjektifnya dan hal ini akan mendorong seseorang untuk berperilaku.

Penelitian mengenai berbagi pengetahuan sudah banyak dilakukan, tetapi pada penelitian sebelumnya banyak menguji niat individu untuk berbagi pengetahuan, seperti penelitian Jolaee, et al. (2013) dan Iqbal et al. (2011). Dalam penelitian ini lebih menguji perilaku aktual individu dalam berbagi pengetahuan, yang objek penelitiannya adalah dosen akuntansi. Penelitian ini ingin menguji kembali yang dilakukan Jolaee, et al. (2013) dengan objek penelitian Dosen Akuntansi kota Bengkulu.

Selain itu, peneliti sebelumnya menggunakan variabel kepercayaan untuk mempengaruhi niat individu untuk berbagi pengetahuan, sedangkan dalam penelitian ini menggunakan variabel Perceived Behavior Control untuk mempengaruhi perilaku berbagi pengetahuan. Dari suatu perilaku yang dikendalikan tersebut individu dapat mengendalikan sikap dan keyakinannya terhadap perilaku berbagi pengetahuan, individu akan menganggap adanya suatu kemudahan atau kesulitan ketika berbagi pengetahuan, karena perilaku yang dikendalikan ini akan mempengaruhi perilaku aktualnya untuk berbagi pengetahuan, sedangkan jika kepercayaan digunakan untuk mempengaruhi perilaku individu, individu tidak dapat mengendalikan suatu perilaku karena didasarkan pada keyakinan dan kepercayaan untuk melakukan suatu perilaku tanpa memandang hambatan apa yang akan terjadi, sehingga penelitian ini menggunakan perceived behavior control untuk mempengaruhi perilaku berbagi pengetahuan.

\section{Kajian Literatur \\ Theory of Planned Behavior}

Theory of Planned Behavior (TPB) yang dikembangkan oleh Ajzen, fokus utamanya adalah niat individu untuk melakukan perilaku tertentu. TPB merupakan pengembangan dari Theory of Reasoned Action atau TRA (Ajzen dan Fishbein, 1980). Ajzen (1991) menjelaskan ada tiga faktor penentu niat untuk berprilaku yaitu: (1) attitude toward behavior (sikap terhadap perilaku), (2) subjective norm (norma subjektif), dan (3) perceived behavior control (kontrol perilaku yang dipersepsikan). Attitude toward behavior menunjukkan tingkatan seseorang mempunyai evaluasi yang baik atau yang kurang baik tentang perilaku tertentu. Norma subjektif adalah tekanan sosial yang dirasakan untuk melakukan atau tidak melakukan perilaku. Kontrol perilaku yang dipersepsikan adalah kesulitan atau

kemudahan yang dirasakan dalam melakukan perilaku tertentu.

Niat individu untuk menampilkan suatu perilaku adalah kombinasi dari sikap untuk menampilkan perilaku tersebut dan norma subjektif. Dalam penelitian ini tidak menguji niat individu tetapi lebih kepada perilaku individu, yang mana tingkah laku seseorang tidak hanya dipengaruhi oleh niatnya tetapi juga perilaku aktualnya. TPB dapat digunakan untuk memprediksi apakah seseorang akan melakukan atau tidak melakukan suatu perilaku.

Teori ini tidak hanya menekankan pada rasionalitas dari tingkah laku manusia, tetapi juga pada keyakinan bahwa target tingkah laku berada di bawah kontrol kesadaran individu tersebut atau suatu tingkah laku tidak hanya bergantung pada niat seseorang, melainkan juga pada faktor lain yang tidak ada dibawah kontrol dari individu, misalnya 
ketersediaan sumber dan kesempatan untuk menampilkan tingkah laku tersebut (Ajzen, 2005). Dari sinilah Ajzen memperluas teorinya dengan menekankan peranan dari kemampuan tersebut yang kemudian disebut sebagai perceived behavioral control (Vaughan \& Hogg, 2005).

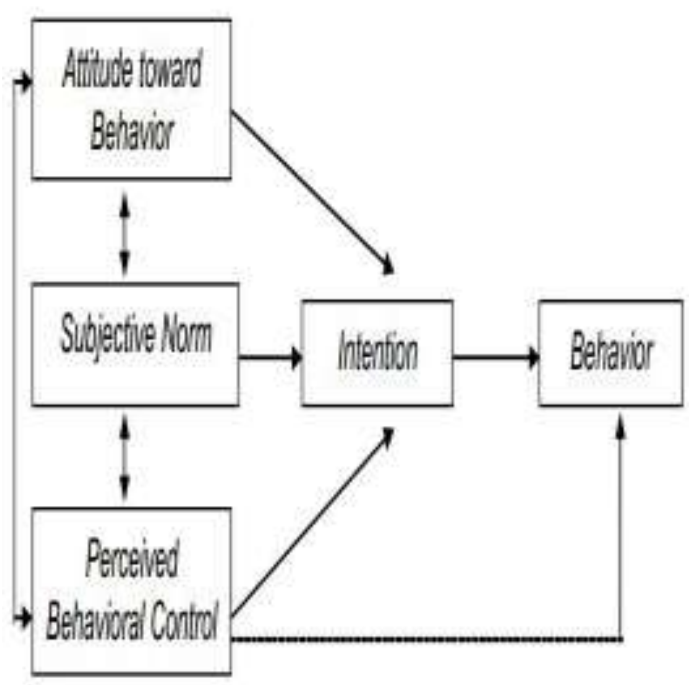

Sumber: Theory of Planned Behavior, Ajzen (1991)

Gambar 1 Theory of Planned Behavior

\section{Perilaku (Behavior)}

Manusia biasanya berperilaku dengan cara yang masuk akal, mereka mempertimbangkan perilakunya berdasarkan informasi yang tersedia, dan secara implisit dan ekplisit juga mempertimbangkan akibat dari tindakan mereka (Ajzen, 2006). Ajzen (2005) menjelaskan, perilaku didasarkan faktor kehendak yang melibatkan pertimbanganpertimbangan untuk melakukan atau tidak melakukan suatu perilaku, dimana dalam prosesnya berbagai pertimbangan tersebut akan membentuk intensi untuk melakukan perilaku.

TPB menyatakan bahwa perilaku merupakan fungsi dari informasi atau keyakinan yang menonjol mengenai perilaku tersebut. Seseorang dapat memiliki berbagi macam keyakinan terhadap suatu perilaku, namun ketika dihadapkan pada suatu kejadian tertentu, hanya sedikit dari keyakinan tersebut yang timbul untuk mempengaruhi perilaku. Sedikit keyakinan inilah yang menonjol dalam mempengaruhi perilaku individu (Ajzen, 1991), sehingga dalam penelitian ini menguji perilaku berdasarkan kostruk dari theory of planned behavior yang langsung mempengaruhi suatu perilaku.

\section{Attitude toward behavior (Sikap Terhadap Perilaku)}

Menurut TPB seseorang yang percaya bahwa menampilkan perilaku tertentu akan mengarahkan pada hasil yang positif dan memiliki sikap favorable terhadap ditampilkannya perilaku, sedangkan orang yang percaya bahwa menampilkan tingkah laku tertentu akan mengarahkan pada hasil yang negatif, maka ia akan memiliki sikap unfavorable (Ajzen, 1988).

Ajzen (2005) mengemukakan bahwa attitude toward behavior ini ditentukan oleh keyakinan yang diperoleh mengenai konsekuensi dari suatu perilaku atau disebut juga behavioral beliefs. Keyakinan

berkaitan dengan penilaian-penilaian subjektif seseorang terhadap dunia sekitarnya, pemahaman mengenai diri dan lingkungannya. Keyakinan ini dapat memperkuat sikap terhadap perilaku berdasarkan evaluasi dari data yang diperoleh bahwa perilaku itu dapat memberikan keuntungan bagi pelakunya.

\section{Norma Subjektif}

Norma subjektif adalah persepsi individu terhadap tekanan sosial yang dirasakan untuk melakukan atau tidak melakukan suatu perilaku (Ajzen, 1991). Norma subjektif ditentukan oleh adanya keyakinan normatif (normative belief) dan keinginan untuk mengikuti (motivation to comply) (Ajzen, 2005). Norma subjektif dipengaruhi oleh keyakinan dan motivasi yang mana orang lain tersebut ikut terlibat didalamnya. Orang lain disini ialah orang tua, pasangan, teman dekat, rekan kerja atau lainnya.

Norma subjektif tidak hanya ditentukan oleh harapan orang-orang sekitar yang berpengaruh bagi individu, tetapi juga ditentukan oleh keinginan untuk mengikuti. 
Secara umum, individu yang yakin bahwa kebanyakan orang-orang sekitar yang berpengaruh bagi individu akan menyetujui dirinya menampilkan perilaku tertentu, dan adanya motivasi untuk mengikuti perilaku tertentu, akan merasakan tekanan sosial untuk melakukannya, hal ini akan menyebabkan dirinya memiliki norma subjektif yang menempatkan pengaruh pada dirinya untuk menghindari melakukan perilaku tersebut (Ajzen, 2005).

\section{Perceived Behavior Control}

Perceived behavior control atau kontrol perilaku yang dipersepsikan mengacu pada persepsi seseorang terhadap sulit tidaknya melaksanakan perilaku yang diinginkan, terkait dengan keyakinan akan tersedia atau tidaknya sumber dan kesempatan yang diperlukan untuk mewujudkan perilaku tertentu dengan mencerminkan pengalaman masa lalu serta antisipasi terhadap hambatan dan rintangan (Ajzen, 1991).

Ajzen (2005) menjelaskan kontrol perilaku sebagai fungsi yang didasarkan oleh belief yang disebut control belief yaitu belief individu mengenai ada atau tidak adanya faktor yang mendukung atau menghalangi individu untuk memunculkan sebuah perilaku. Semakin individu merasakan banyak faktor pendukung dan sedikit faktor penghambat untuk dapat melakukan suatu perilaku, maka lebih besar kontrol yang mereka rasakan atas perilaku tersebut dan begitu juga sebaliknya, semakin sedikit individu merasakan factor pendukung dan banyak faktor penghambat untuk dapat melakukan suatu perilaku, maka individu akan cenderung mempersepsikan diri sulit untuk melakukan perilaku tersebut (Ajzen, 2005).

\section{Self Efficacy}

Self efficacy yang merupakan penilaian individu terhadap kemampuan dan kompetensinya untuk melakukan suatu tugas, mencapai suatu tujuan, dan menghasilkan sesuatu (Baron dan Byrne 2000). Dalam hal ini self efficacy sebagai keyakinan dalam kemampuan seseorang untuk mengatur dan melaksanakan tindakan tertentu untuk mencapai suatu keberhasilan. Self efficacy berpengaruh besar terhadap perilaku karena adanya sebuah keyakinan, keyakinan ini bisa menentukan bagaimana seseorang tersebut berpikir, berprilaku, dan merasa (Bandura, 1997). Ketika seseorang berpikir bahwa keahlian mereka dapat

meningkatkan efisiensi kerja dan meningkatkan produktivitas, sikap mereka untuk berbagi pengetahuan akan berubah dan sebagai hasilnya mereka akan cenderung untuk berbagi pengetahuan pada orang lain.

\section{Jaringan Sosial}

Jaringan sosial merupakan suatu hubungan sosial yang diikat oleh adanya kepercayaan dan kepercayaan itu dipertahankan dan dijaga oleh norma-norma yang ada, yang pada dasarnya jaringan sosial terbentuk karena adanya rasa saling tahu, saling menginformasikan, saling mengingatkan, dan saling membantu dalam melaksanakan ataupun mengatasi sesuatu (Lawang, 2005). Seorang yang berkinerja akan mendapatkan pengetahuan yang lebih dan akan mendapatkan informasi yang berharga dari rekan kerja melalui jaringan sosialnya (Davenport, 2005).

\section{Extrinsic Reward}

Extrinsic reward atau penghargaan ekstrinsik merupakan penghargaan dalam bentuk finansial, material, atau sosial dari lingkungan. Penghargaan ini merupakan penghargaan yang bersifat eksternal yang diberikan terhadap kinerja yang telah diberikan pekerja (Kreitner dan Kinicki, 2005).

\section{Dukungan Organisasi}

Dukungan organisasi diartikan sebagai seberapa jauh karyawan beranggapan bahwa kontribusi mereka dihargai oleh organisasi dan organisasi tersebut peduli dengan kesejahteraan mereka atau seberapa jauh organisasi ada untuk mereka (Indra, 2014). Randall et al. (1999) menyatakan bahwa 
organisasi yang mendukung adalah organisasi yang merasa bangga terhadap pekerja mereka, memberi kompensasi dengan adil, dan mengikuti kebutuhan pekerjanya.

\section{Pengembangan Hipotesis}

Self Efficacy dan Attitude toward behavior

Penelitian Jolaee et al. (2013) dan Iqbal et al. (2011) menunjukkan bahwa self efficacy berpengaruh positif terhadap attitude toward behavior berbagi pengetahuan, semakin tinggi keyakinan seseorang terhadap suatu kemampuan yang dimiliki, maka semakin tinggi juga kesempatan untuk berbagi pengetahuan. Ketika keyakinan terhadap pengetahuan meningkat dan mendapatkan kepercayaan dari dalam diri untuk melakukan suatu perilaku dan berpikir bahwa keahlian mereka dapat meningkatkan efisiensi kerja, meningkatkan produktifitas, sikap mereka untuk berbagi pengetahuan akan berubah dan sebagai hasilnya mereka akan cenderung untuk berbagi pengetahuan kepada orang lain (Jolaee et al., 2013).

Individu akan beranggapan bahwa keahlian, pengetahuan, dan pengalamannya dapat meningkatkan produktivitas suatu institusi atau perguruan tinggi. Dari

anggapan tersebutlah yang akan mempengaruhi sikap untuk berbagi pengetahuan karena hal tersebut bermanfaaat, dan sebagai hasilnya mereka akan cenderung untuk berperilaku positif. Berdasarkan hal di atas, maka dirumuskan hipotesis pertama yaitu:

H1: Self Efficacy berpengaruh positif terhadap Attitude Toward Behavior

\section{Jaringan Sosial dan Attitude toward behavior}

Jaringan social terbentuk karena adanya rasa saling tahu, saling menginformasikan, saling mengingatkan, dan saling membantu dalam melaksanakan ataupun mengatasi sesuatu (Lawang, 2005). Penelitian Jolaee et al. (2013) dan Iqbal et al. (2011) menunjukkan bahwa jaringan sosial berpengaruh positif terhadap attitude toward behavior. Semakin tinggi jaringan sosial yang dimiliki seseorang semakin tinggi juga attitude toward behavior yang akan ditampilkan. Ketika seseorang memiliki jaringan sosial yang sangat luas maka kesempatan untuk mendapatkan pengetahuan baru akan banyak didapatkan, selain itu jaringan sosial memberikan peluang untuk meningkatkan kontak interpersonal dengan orang lain, ketika seseorang anggota dari suatu jaringan tersebut, maka akan meningkatkan interpersonalnya dan hal ini akan mempengaruhi sikap mereka untuk berbagi pengetahuan.

Dengan adanya suatu jaringan sosial dari suatu organisasi akan mendapatkan banyak pengetahuan dan pengalaman yang didapatkan. Kegiatan berbagi pengetahuan dan pengalaman ini akan menumbuhkan sikap saling percaya antar individu karena telah mendapatkan pengetahuan baru dari suatu jaringan sosial tersebut. Berdasarkan hal di atas, maka dirumuskan hipotesis kedua yaitu:

H2: Jaringan Sosial berpengaruh positif terhadap Attitude Toward Behavior

\section{Extrinsic Reward dan Attitude toward behavior}

Extrinsic reward adalah sebuah penghargaan yang merupakan hasil dari pekerjaan yang dilakukan oleh seseorang. Penghargaan ini dapat berupa gaji dan upah, jaminan sosial, interpersonal reward, promosi jabatan, profit sharing dan lainnya (Gibson, Ivancevich dan Donnely, 1991).

Dalam penelitian Jolaee et al. (2013 dan Iqbal et al. (2011) extrinsic reward berpengaruh negatif terhadap attitude toward behavior, tetapi banyak individu yang melakukan suatu perilaku dikarenakan adanya sebuah timbal balik atas suatu kegiatan yang telah dilakukan. Dengan adanya suatu imbalan atau penghargaan akan mempengaruhi individu untuk berbagi pengetahuan karena adanya suatu penghargaan yang didapat berupa insentif, dana hibah pengabdian masyarakat, promosi jabatan dan profit sharing. Semakin tinggi extrinsic reward yang didapatkan seseorang 
maka semakin tinggi juga sikap untuk berbagi pengetahuannya. Berdasarkan hal di atas, maka dirumuskan hipotesis ketiga yaitu:

H3: Extrinsic Reward berpengaruh positif terhadap Attitude Toward Behavior

\section{Dukungan Organisasi dan Norma Subjektif}

Dukungan organisasi diartikan sebagai seberapa jauh karyawan beranggapan bahwa kontribusi mereka dihargai oleh organisasi dan organisasi tersebut peduli dengan kesejahteraan mereka atau seberapa jauh organisasi ada untuk mereka (Indra, 2014). Pada penelitan Jolaee et al. (2013) dan Iqbal et al. (2011) dukungan organisasi berpengaruh positif terhadap norma subjektif. Semakin tinggi dukungan dari institusi untuk melakukan suatu perilaku semakin tinggi pula tekanan sosial yang dirasakan atau norma subjektif.

Dukungan organisasi merupakan salah satu faktor yang mempengaruhi norma subjektif, sebagaimana norma subjektif adalah suatu keyakinan dan motivasi orang lain, serta harapan orang sekitar yang berpengaruh bagi individu yang ditentukan oleh keinginan untuk melakukan atau tidak melakukan perilaku tersebut. Berdasarkan hal di atas, maka dirumuskan hipotesis keempat yaitu:

H4: Dukungan Organisasi berpengaruh positif terhadap Norma Subjektif

\section{Attitude Toward Behavior dan Perilaku Berbagi Pengetahuan Akuntansi}

Attitude toward behavior merupakan persepsi dari individu yang berkeyakinan bahwa ketika ia melakukan suatu perilaku akan muncul sikap perasaan positif atau negatif yang akan mempengaruhinya untuk berperilaku. Dosen akuntansi akan beranggapan bahwa berbagi pengetahuan merupakan suatu hal yang bermanfaaat karena akan mendapatkan nilai positif dari dalam diri dan memiliki sikap perasaan senang dan suka ketika individu berbagi pengetahuan, dari pandangan tersebutlah akan muncul sebuah perilaku yaitu berbagi pengetahuan.

Penelitian Jolaee et al. (2013) dan Iqbal et al. (2011) menujukaan bahwa attitude toward behavior berpengaruh positif terhadap niat berbagi pengetahuan, sebagaimana niat akan mempengaruhi perilaku itu sendiri. Jika individu memiliki sikap positif terhadap suatu perilaku berbagi pengetahuan maka semakin besar peluang individu tersebut untuk melakukan kegiatan berbagi pengetahuan. Sebaliknya, jika individu bersikap negatif terhadap berbagi pengetahuan maka kecil kemungkinannya ia untuk berbagi pengetahuan. Berdasarkan hal di atas, maka dirumuskan hipotesis kelima yaitu:

Hs: Attitude Toward Behavior berpengaruh positif terhadap Perilaku Berbagi Pengetahuan Akuntansi

\section{Norma Subjektif dan Perilaku Berbagi Pengetahuan Akuntansi}

Norma subjektif adalah persepsi individu terhadap tekanan sosial yang dirasakan untuk melakukan atau tidak melakukan suatu perilaku (Ajzen, 1991). Penelitian Iqbal et al. (2011) menunjukkan bahwa norma subjektif berpengaruh positif terhadap niat berbagi pengetahuan, sebagaimana niat akan mempengaruhi perilaku berbagi pengetahuan. Semakin tinggi tekanan sosial dan dukungan dari orang-orang terdekat semakin tinggi juga perilaku seseorang untuk berbagi pengetahuan.

Individu akan beranggapan bahwa adanya sebuah dukungan dari orang-orang terdekat yang dirasakan untuk menginginkannya terlibat dalam suatu perilaku berbagi pengetahuan atau tidak, dari perasaan tersebutlah akan muncul sebuah perilaku positif yang akan mempengaruhi dirinya untuk melakukan suatu perilaku berbagi pengetahuan, oleh karenanya hipotesis keenam yaitu:

H6: Norma Subjektif berpengaruh positif terhadap Perilaku Berbagi Pengetahuan Akuntasi 


\section{Perceived Behavior Control dan Perilaku Berbagi Pengetahuan}

Perceived behavior control atau kontrol perilaku yang dipersepsikan mengacu pada persepsi seseorang terhadap sulit tidaknya melaksanakan perilaku yang diinginkan, terkait dengan keyakinan akan tersedia atau tidaknya sumber dan kesempatan yang diperlukan untuk mewujudkan perilaku tertentu dengan mencerminkan pengalaman masa lalu serta antisipasi terhadap hambatan dan rintangan (Ajzen, 1991. Penelitian Ho et al. (2011) menunjukkan bahwa perceived behavior control berpengaruh positif terhadap niat berbagi pengetahuan dari sebuah niat akan mempengaruhi individu untuk berperilaku. Semakin tinggi persepsi suatu kemudahan terhadap perilaku berbagi pengetahuan maka semakin tinggi pula perilaku yang akan dilakukannaya.

Individu akan berkeyakinan bahwa pengalaman terhadap suatu perilaku dipengaruhi oleh informasi yang didapat oleh orang lain, dari sebuah informasi tersebut dapat menjadi suatu pertimbangan untuk melakukan suatu perilaku. Ketika seseorang yakin bahwa ia dapat terlibat dalam perilaku berbagi pengetahuan dengan relatif mudah dan sedikit kendala, maka akan memiliki dampak positif terhadap perilakunya. Oleh karenanya hipotesis ketujuh yaitu:

H7: Perceived Behavior Control berpengaruh positif terhadap Perilaku Berbagi Pengetahuan Akuntansi

\section{Metode Penelitian}

Jenis penelitian pada penelitian ini ialah kuantitatif. Teknik pengambilan sampel pada umumnya dilakukan secara random, pengumpulan data menggunakan instrumen penelitian, analisis data dan bersifat kuantitatif dengan tujuan untuk menguji hipotesis yang telah ditetapkan.

Variabel yang digunakan dalam penelitian ini adalah variabel laten, variabel laten yaitu endogen dan eksogen. Variabel eksogen dalam penelitian ini terdiri dari self efficacy, jaringan sosial, extrinsic reward, dukungan organisasi, dan perceived behavior control. Sedangkan variabel endogen dalam penelitian ini adalah attitude toward behavior, norma subjektif dan perilaku berbagi pengetahuan akuntansi.

Variabel self efficacy diukur menggunakan instrumen yang dikembangkan dan disesuaikan kembali dari penelitian Jolaee et al. (2013) yang berasal dari penelitian Bock et al. (2005). Dimensi untuk variabel ini adalah

membantu menyelesaikan masalah, keyakinan dapat meningkatan proses kerja, mancapai target kinerja, dan merasa akan mendapatkan peluang yang sama.

Jaringan sosial diukur menggunakan instrumen yang dikembangkan dan disesuaikan kembali dari penelitian Jolaee $e t$ al. (2013) yang berasal dari penelitian Kim dan Lee (2006). Dimensi untuk variabel ini adalah adanya forum, mendapatkan informasi, mendapatkan pengalaman, berbagi diluar organisasi.

Extrinsic reward dalam penelitian ini diukur menggunakan instrumen yang dikembangkan dan disesuaikan kembali dari penelitian Jolaee et al. (2013) yang berasal dari penelitian Bock et al. (2005). Dimensi untuk variabel ini adalah uang, insentif, promosi jabatan, dan dana hibah.

Dukungan organisasi dalam penelitian ini diukur menggunakan instrumen yang dikembangkan dan disesuaikan kembali dari penelitian Jolaee et al. (2013) yang berasal dari penelitian Sveiby dan Simons (2002). Dimensi untuk variabel ini adalah dukungan teknologi informasi dari institusi,

menyediakan fasilitas, mendukung pembentukan jaringan sosial, fasilitas dana untuk kegiatan.

Attitude toward behavior pada penelitian ini diukur menggunakan instrumen yang dikembangkan dan disesuaikan kembali dari penelitian Jolaee $e t$ al. (2013) yang berasal dari penelitian So dan Bolloju (2005) serta Bock et al. (2005). Dimensi untuk variabel ini adalah suatu ide yang bagus, memberikan manfaat, merupakan hal yang menyenangkan, pengalaman yang berharga. Sedangkan indikator penelitian ini adalah berbagi pengetahuan merupakan ide yang bagus, 
berbagi pengalaman dan keahlian memberikan manfaat, bertemu berbagi pengalaman dan pengetahuan mengenai informasi tentang akuntansi merupakan hal yang menyenangkan, berbagi pengetahuan di suatu organisasi atau forum dosen merupakan pengalaman yang berharga.

Norma subjektif diukur menggunakan instrumen yang dikembangkan dan disesuaikan kembali dari penelitian Jolaee $e t$ al. (2013) yang berasal dari penelitian Bock et al. (2005) dan Lu et al. (2006). Dimensi untuk variabel ini adalah dukungan keluarga, rekan kerja, orang yang dianggap penting, dan mendorang rekan kerja lainnya.

Perceived behavior control diukur menggunakan instrumen yang dikembangkan dan disesuaikan kembali dari penelitian Ho et al. (2011). Dimensi untuk variabel ini adalah persepsi kemudahan, berdasarkan pengalaman, ikut serta berbagi pengetahuan, dukungan sarana dan prasarana.

Perilaku berbagi pengetahuan dalam penelitian ini menjelaskan bagaimana seseorang telah atau pernah melakukan suatu perilaku tersebut, misalnya memanfaatkan teknologi apa saja, kegiatan untuk menunjang pengetahuan baru yang diikuti, melakukan kerjasama, berdiskusi, dan berbagai pengetahuan dan keahlian yang berasal dari pelatihan, yang dinilai dari pernah tidaknya melakukan suatu perilaku tersebut. Dimensi untuk variabel ini adalah teknologi yang digunakan, kegiatan yang diikuti, teamwork, diskusi, dan berbagi keahlian.

Populasi dalam penelitian ini ialah seluruh dosen akuntansi yang bekerja di perguruan tinggi negeri maupun swasta yang ada di Kota Bengkulu. Sampel pada

penelitian ini ditentukan dengan menggunakan teknik purposive sampling. Kriteria dalam sampel ini yaitu dosen akuntansi yang aktif bekerja di perguruan tinggi negeri dan perguruan tinggi swasta di Kota Bengkulu, yang mengajar di jurusan akuntansi dan mata kuliah akuntansi. Sehingga total dosen akuntansi yang menjadi sampel sebanyak 62 orang, dari
Universitas Bengkulu sebanyak 26 orang, Universitas Muhammadiyah Bengkulu sebanyak 22 orang, Universitas Dehasen sebanyak 8 orang, dan Universitas Prof. Dr. Hazairin, SH, sebanyak 6 orang.

Data yang digunakan dalam penelitian ini adalah data primer. Data diperoleh melalui pengisian kuesioner oleh responden, teknik pengumpulan data yang dilakukan secara kuesioner ini adalah dengan cara memberikan seperangkat pernyataan kepada responden.

Analisis data dalam penelitian ini menggunakan pendekatan Partial Least Square (PLS). PLS didefinisikan oleh dua persamaan, yaitu inner model dan outer model. Inner model menentukan spesifikasi hubungan antara konstrak dan konstrak yang lain, sedangkan outer model menentukan spesifikasi hubungan antara konstrak dan indikator-indikatornya. Outer Model (Model Pengukuran) digunakan untuk mengetahui validitas dan reliabilitas yang menghubungkan indikator dengan konstruk atau variabel latennya.

Pengujian inner model atau model struktural dilakukan untuk melihat hubungan antara konstruk, nilai signifikansi dan $R$-square dari model penelitian. Pengujian hipotesis dilakukan dengan

proses bootstrapping/ resampling bootstrapping. Pengujian hipotesis yang diajukan dapat dilihat dari besarnya nilai tstatistik. Kriteria untuk menolak dan menerima hubungan yang diajukan dapat dilihat dari perbandingan antar nilai tstatistik dan t-tabel. Jika nilai t-statistik > ttabel $(1,96)$ maka hipotesis yang diajukan diterima (Ghozali, 2014).

\section{Hasil Penelitian dan Pembahasan}

Jumlah kuesioner yang disebarkan sebanyak 52 eksemplar, dan total kuesioner kembali sebanyak 45 eksemplar dan kuesioner yang dapat digunakan sebanyak 43 eksemplar. Pengumpulan data pada penelitian ini dilakukan dengan menyebarluaskan secara langsung, waktu yang diperlukan untuk pengumpulan data 
24 desember 2016 sampai dengan 13 Januari 2017.

Adapun profil responden yang berpartisipasi dalam penelitian ini ditunjukkan dalam Tabel 1 berikut ini:

\section{Tabel 1}

Statistik Deskripsi Responden

\begin{tabular}{|c|c|c|}
\hline Uraian & Frekuensi & $\%$ \\
\hline $\begin{array}{c}\text { Jenis Kelamin: } \\
\text { Laki-Laki }\end{array}$ & 20 & $46,51 \%$ \\
\hline Perempuan & 23 & $53,49 \%$ \\
\hline Total Responden & 43 & $100 \%$ \\
\hline Tingkat Pendidikan & & \\
S1 & 0 & $0 \%$ \\
S2 & 39 & $90,70 \%$ \\
S3 & 4 & $9,30 \%$ \\
\hline Total Responden & 43 & $100 \%$ \\
\hline Lama Bekerja & & \\
1-10 Tahun & 18 & $41,87 \%$ \\
11-20 Tahun & 22 & $51,16 \%$ \\
21-30 Tahun & 3 & $6,98 \%$ \\
\hline Total Responden & 43 & $100 \%$ \\
\hline Organisasi & & \\
IAI & 37 & $86,04 \%$ \\
Selain IAI & 6 & $13,96 \%$ \\
\hline Total Responden & 43 & $100 \%$ \\
\hline
\end{tabular}

Responden penelitian mayoritas responden adalah perempuan yaitu sebanyak 23 orang $(53,49 \%)$, tingkat pendidikan responden mayoritas tingkat pendidikan responden adalah Strata 2 (S2) yaitu sebanyak 39 orang $(90,70 \%)$, hal ini merupakan sesuai dengan peraturan menteri riset, teknologi, dan pendidikan tinggi nomor 26 tahun 2015 tentang register pendidik pada perguruan tinggi, yang mana syarat mengajar di program diploma dan program sarjana adalah ijazah minimum program magister. Dilihat dari lamanya masa kerja responden, untuk masa kerja 11-20 tahun sebanyak 22 orang $(51,16 \%)$, yang artinya dosen akuntansi Kota Bengkulu sudah memiliki pengalaman kerja yang baik untuk berbagi pengetahuan. Dilihat dari organisasi yang diikuti responden mayoritasnya adalah IAI (Ikatan Akuntan Indonesia) yaitu sebanyak $37(86,04 \%)$ hal ini membuktikan bahwa dosen akuntansi kota Bengkulu juga aktif dikegiatan organisasi Ikatan Akuntan Indonesia (IAI) dan lainnya.

Berdasarkan statistik deskriptif, self efficacy (SE) mempunyai rata-rata aktual sebesar 16,60 yang artinya bahwa secara rata-rata responden mempunyai keyakinan bahwa dengan berbagi pengetahuan dapat membantu individu lainnya dalam memecahkan masalah, dapat meningkatkan proses kerja dalam suatu organisasi, dapat membantu institusi dalam mencapai target kinerjanya, dan dengan saling berbagi pengetahuan akan memiliki peluang kemampuan yang sama antar individu. Variabel jaringan sosial memiliki rata-rata aktual sebesar 16,88 yang artinya secara rata-rata responden menilai institusi tempat mereka bekerja sudah terdapat forum dosen, dan dengan tergabung dalam suatu organisasi sebuah informasi akan mudah didapatkan, serta dengan aktif melakukan kegiatan organisasi pengetahuan dan pengalaman akan didapatkan, selain itu responden juga ikut berbagi pengetahuan di luar organisasi yang diikuti. Untuk variabel extrinsic reward (ER) mempunyai rata-rata aktual sebesar 15,86 yang artinya secara rata-rata responden menilai dengan berbagi pengetahuan akan mendapatkan imbalan yang dapat berupa uang sebagai

penghargaan, mendapakan insentif, mendapatkan tambahan poin untuk promosi jabatan, dan mendapatkan dana hibah atas kegiatan pengabdian masyarakat.

Variabel dukungan organisasi mempunyai rata-rata aktual sebesar 16,60 yang artinya secara rata-rata responden menilai institusi tempat mereka bekerja memiliki teknologi informasi, menyediakan fasilitas untuk kegiatan berbagi pengetahuan, mendukung pembentukan jaringan sosial, dan memberikan fasilitas seperti dana untuk kegiatan berbagi pengetahuan. Untuk variabel attitude toward behavior mempunyai rata-rata aktual sebesar 16,58 yang artinya secara rata-rata responden menilai bahwa berbagi pengetahuan merupakan suatu ide yang bagus, memberikan manfaat, suatu hal yang menyenangkan, dan akan mendapatkan 
pengalaman yang berharga. Variabel norma subjektif mempunyai rata-rata aktual sebesar 16,23 yang artinya secara rata-rata responden menilai bahwa terdapat dukungan dari keluarga, rekan kerja, orang yang dianggap penting serta saran untuk mendorong yang lainnya untuk ikut serta dalam berbagi pengetahuan.

Perceived behavior control mempunyai rata-rata aktual sebesar 16,55 yang artinya secara rata-rata responden menilai dengan pengalaman yang ada, sarana dan prasarana mendukung, banyak yang melakukan kegiatan berbagi pengetahuan, maka kegiatan berbagi pengetahuan dapat dilakukan dengan mudah. Untuk perilaku berbagi pengetahuan akuntansi memiliki rata-rata aktual sebesar 20,23 yang artinya secara rata-rata responden menggunakan media teknologi, mengikuti kegiatan untuk

menunjang pengetahuan, melakukan kerjasama, berdiskusi, serta berbagi keahlian yang didapat dari pelatihan yang diikuti.

Penelitian ini menggunakan model persamaan struktural yang di analisis dengan menggunakan program SmartPLS, kemudian dilakukan evaluasi outer model dengan menggunakan PLS Algorithm.

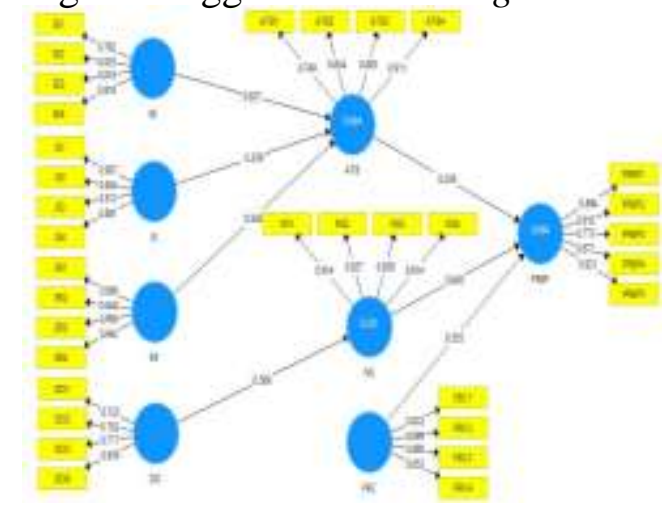

\section{Gambar 2}

\section{Tampilan Hasil PLS Algorithm}

Berdasarkan Gambar 2 menunjukkan, hasil dari perhitungan outer loading untuk semua indikator yang membentuk konstruk/variabel penelitian mempunyai nilai korelasi diatas 0,70 yang artinya indikator suatu konstruk mempunyai validity yang baik.
Nilai cross loading juga menunjukkan discriminant validity yang baik oleh karena nilai korelasi indikator terhadap konstruknya lebih tinggi dibandingkan nilai korelasi indikator dengan konstruk lainnya. Hasil uji validitas konvergen yang diukur dengan melihat skor Average Variance Extracted (AVE). Dari hasil output SmartPLS diatas semua konstruk memiliki nilai AVE diatas 0,50 untuk semua konstruk yang artinya bahwa konstruk memiliki validitas konvergan yang baik.

Di samping uji validitas konstruk, dilakukan juga uji reliabilitas konstruk yang diukur dengan composite reliability dan cronbach's alpha dari blok indikator yang mengukur konstruk. Dari hasil SmartPLS di atas semua konstruk memiliki nilai composite reliability di atas 0,70 dan cronbach's alpha diatas 0,60, sehingga dapat disimpulkan bahwa konstruk memiliki reliabilitas yang baik dan memenuhi kriteria uji reliabilitas.

Setelah model yang diestimasi memenuhi kriteria discriminant validity berikutnya dilakukan pengujian model struktural (inner model). Menilai inner model adalah melihat hubungan antara konstruk laten dengan melihat hasil estimasi koefisien parameter path dan tingkat signifikansinya (Ghozali, 2008).

\section{Tabel 2}

\section{R-Square}

\begin{tabular}{|c|c|}
\hline Variabel & R-Square \\
\hline Attitude Toward Behavior & 0,984 \\
\hline Norma Subjektif & 0,323 \\
\hline $\begin{array}{l}\text { Perilaku Berbagi } \\
\text { Pengetahuan Akuntansi }\end{array}$ & 0,894 \\
\hline
\end{tabular}

Pada Tabel 1 menunjukkan bahwa nilai $\mathrm{R}$-square untuk attitude toward behavior sebesar 0,984 atau 98,4\% artinya variasi variabel attitude toward behavior dipengaruhi oleh perubahan pada variabel self efficacy, jaringan sosial dan extrinsic reward sebesar $98,4 \%$ sedangkan $1,6 \%$ dipengaruhi oleh variabel lain diluar model penelitian ini. Pada variabel norma subjektif mempunyai nilai Rsquare sebesar 0,323 atau $32,3 \%$ artinya variasi variable norma subjektif 
dipengaruhi oleh perubahan variabel dukungan organisasi sebesar 32,3\%, sedangkan $67,7 \%$ dipengaruhi oleh variabel lain diluar model penelitian ini. Nilai Rsquare untuk variabel perilaku berbagi pengetahuan akuntansi mempunyai nilai sebesar 0,894 atau $89,4 \%$ artinya variasi variabel perilaku berbagi pengetahuan akuntansi dipengaruhi oleh perubahan pada variabel attitude toward behavior, norma subjektif, dan perceived behavior control sebesar $\quad 89,4 \%$ sedangkan $10,6 \%$ dipengaruhi oleh variabel lain diluar model penelitian ini.

Dalam PLS pengujian secara statistik setiap hubungan yang dihipotesiskan dilakukan membandingkan nilai t-statistic dengan t-tabel signifikansi $\alpha=5 \% \quad(1,96)$ yang ditunjukkan pada Tabel 2 berikut:

\section{Tabel 3}

Path Coefficient

\begin{tabular}{|l|c|c|c|}
\hline & $\begin{array}{c}\text { Original } \\
\text { sample } \\
\text { estimate } \\
(\mathbf{O})\end{array}$ & $\begin{array}{c}\text { T- } \\
\text { Statistics } \\
(\mathbf{O} \text { /STER } \\
\text { R })\end{array}$ & $\begin{array}{c}\text { T- } \\
\text { Table }\end{array}$ \\
\hline SE->ATB & 0,827 & 5,280 & 1,96 \\
\hline JS->ATB & 0,359 & 2,056 & 1,96 \\
\hline ER->ATB & 0,542 & 4,159 & 1,96 \\
\hline DO->NS & 0,569 & 6,030 & 1,96 \\
\hline ATB->PRBP & 0,329 & 2,699 & 1,96 \\
\hline NS->PRBP & 0,645 & 6,588 & 1,96 \\
\hline PBC->PRBP & 0,555 & 3,238 & 1,96 \\
\hline Sumber: Pen
\end{tabular}

Sumber: Pengolahan data dengan

PLS, 2017

Pada Tabel 1 menunjukkan bahwa pengaruh self efficacy terhadap attitude toward behavior dengan koefisien sebesar 0,827. Nilai t-statistic $(5,280)>\mathrm{t}$-tabel (1,96), menunjukkan bahwa hipotesis 1 yang menyatakan self efficacy berpengaruh positif terhadap attitude toward behavior diterima.

Untuk pengaruh jaringan sosial terhadap attitude toward behavior dengan koefisien sebesar 0,359. Hasil perhitungan tstatistic $(2,056)>$ t-tabel $(1,96)$, menunjukkan bahwa hipotesis 2 yang menyatakan jaringan sosial berpengaruh positif terhadap attitude toward behavior diterima.
Untuk pengaruh extrinsic reward terhadap attitude toward behavior dengan koefisien sebesar 0,542. Hasil perhitungan tstatistic $(4,159)>$ t-tabel $(1,96)$, menunjukkan bahwa hipotesis 3 yang menyatakan extrinsic reward berpengaruh positif terhadap attitude toward behavior diterima.

Untuk pengaruh variabel dukungan organisasi terhadap norma subjektif dengan koefisien sebesar 0,569. Hasil perhitungan tstatistic $(6,030)>$ t-tabel $(1,96)$, menunjukkan bahwa hipotesis 4 yang

menyatakan dukungan organisasi berpengaruh positif terhadap norma subjekti diterima.

Pengaruh variabel attitude toward behavior terhadap perilaku berbagi pengetahuan dengan koefisien sebesar 0,329 . Hasil perhitungan t-statistic $(2,699)$

$>$ t-tabel $(1,96)$, menunjukkan bahwa hipotesis 5 yang menyatakan attitude toward behavior berpengaruh positif terhadap perilaku berbagi pengetahuan akuntansi diterima.

Pengaruh norma subjektif terhadap perilaku berbagi pengetahuan akuntansi dengan koefisien sebesar 0,645. Hasil perhitungan t-statistic $(6,588)>\mathrm{t}$-tabel $(1,96)$, menunjukkan bahwa hipotesis 6 yang menyatakan norma subjektif berpengaruh positif terhadap perilaku berbagi pengetahuan akuntansi diterima.

Untuk pengaruh perceived behavior control terhadap perilaku berbagi pengetahuan akuntansi dengan koefisien sebesar 0,555. Hasil perhitungan t-statistic $(3,238)>$ t-tabel $(1,96)$, menunjukkan bahwa hipotesis 7 yang menyatakan perceived behavior control berpengaruh positif terhadap perilaku berbagi pengetahuan akuntansi dengan demikian diterima.

\section{Self Efficacy dan Attitude Toward Behavior}

Hipotesis pertama menyatakan bahwa self efficacy berpengaruh positif terhadap attitude toward behavior secara empiris terbukti didukung. Hasil pengujian ini 
menunjukkan bahwa self efficacy mempunyai pengaruh dalam meningkatkan keyakinan individu untuk berbagi pengetahuan, sehingga sebagai hasilnya antar dosen akuntansi dapat saling membantu, saling bekerjasama, saling

menginformasikan. Kegiatan berbagi pengetahuan antar dosen ini juga dapat meningkatkan efisiensi kerja, meningkatkan produktifitas dan mencapai target kinerja di suatu institusi.

Hasil penelitian ini mendukung penelitian Jolaee et al. (2013) dan Iqbal et al. (2013) yang menjelaskan bahwa ketika keyakinan terhadap pengetahuan meningkat dan mendapatkan kepercayaan dari dalam diri untuk melakukan suatu perilaku dan berpikir bahwa keahlian mereka dapat meningkatkan efisiensi kerja, meningkatkan produktifitas, sikap mereka untuk berbagi pengetahuan akan berubah dan sebagai hasilnya mereka akan cenderung untuk berbagi pengetahuan kepada orang lain. Hasil penelitian ini mendukung Theory of Planned Behavior yang menyatakan bahwa self efficacy merupakan faktor dari attitude toward behavior dalam penelitian Jolaee et al. (2013), sedangkan attitude toward behavior merupakan salah satu faktor pembentuk dari niat untuk melakukan suatu perilaku.

\section{Jaringan Sosial dan Attitude Toward Behavior}

Hipotesis kedua menyatakan bahwa jaringan sosial berpengaruh positif terhadap attitude toward behavior, secara empiris terbukti didukung. Hasil pengujian ini menunjukkan bahwa jaringan sosial mempunyai pengaruh terhadap individu, karena individu menganggap dengan adanya jaringan sosial pengetahuan, pengalaman, informasi terbaru akan lebih mudah didapatkan, selain itu nuga jaringan sosial mempermudah antar individu untuk bertukar pikiran. Selain itu juga dengan adanya jaringan sosial disuatu institusi mempermudah individu untuk bertukar pikiran, diskusi, memberikan solusi, dan memecahkan masalah, sehingga target kinerja akan tercapai.

Hasil penelitian ini sesuai dengan pernyataan Jolaee et al. (2013) yang menyatakan bahwa dengan adanya suatu jaringan sosial, akan memudahkan dan mempengaruhi sikap tentang berbagi ide dan pengetahuan didalam suatu jaringan sosial tersebut. Hasil pada hipotesis kedua mendukung penelitian Jolaee et al. (2013) dan Iqbal et al. (2013) yang menunjukkan bahwa jaringan sosial berpengaruh positif terhadap attitude toward behavior.

\section{Extrinsic Reward dan Attitude toward behavior}

Hipotesis ketiga menyatakan bahwa extrinsic reward berpengaruh positif terhadap attitude toward behavior berbagi pengetahuan akuntansi secara empiris terbukti didukung. Hasil pengujian ini menunjukkan bahwa extrinsic reward mempunyai pengaruh keyakinan individu ketika ada suatu penghargaan yang diberikan maka individu cenderung akan melakukan sesuatu, seperti mendapatkan insentif. Selain itu individu akan mendapatkan interpersonal reward seperti nama baik ketika melakukan suatu kegiatan yang positif, selain individu institusi tempat individu bekerja juga mendapatkan nama baik.

Hasil pada hipotesis ketiga mendukung penelitian Liebowitz (1999), O'Reilly dan Pondy (1980) Quinn et al. (1996) dalam Jolaee et al. (2013) yang menunjukkan bahwa extrinsic reward berpengaruh positif signifikan terhadap attitude toward behavior. Jolaee et al. (2013) menjelaskan bahwa dengan adanya suatu imbalan atau penghargaan dapat memotivasi untuk melakukan suatu perilaku sebagai hasilnya keberhasilan pencapaian kegiatan dan tugas dilakukan dengan baik karena adanya suatu penghargaan yang diberikan.

Hasil penelitian ini mendukung Theory of Planned Behavior yang menyatakan bahwa extrinsic reward merupakan faktor dari attitude toward behavior dalam penelitian Jolaee et al. (2013), sedangkan 
attitude toward behavior merupakan salah satu faktor pembentuk dari niat untuk melakukan suatu perilaku.

\section{Dukungan Organisasi dan Norma Subjektif}

Hipotesis keempat menyatakan bahwa dukungan organisasi berpengaruh positif terhadap norma subjektif secara empiris terbukti didukung. Hasil pengujian ini menunjukkan bahwa dukungan organisasi yang dalam hal ini instititusi tempat responden bekerja mendukung kegiatan berbagi pengetahuan, hal ini didukung oleh beberapa fasilitas seperti teknologi informasi menyediakan sarana untuk menyelenggarakan kegiatan berbagi

pengetahuan (seminar, workshop), mendukung pembentukan jaringan sosial (organisasi atau grup), dan fasilitas dana untuk kegiatan berbagi pengetahuan (seminar, mendatangkan dosen perguruan tinggi luar).

Hasil ini mendukung penelitian Jolaee et al. (2013) dan Iqbal et al. (2011) yang menemukan bahwa dukungan organisasi berpengaruh positif terhadap norma subjektif. Jolaee et al. (2013) menjelaskan bahwa organisasi memberikan sumber daya yang tersedia, pelatihan, insentif, dan menghilangkan hambatan dalam berbagi pengetahuan, sehingga kegiatan berbagi pengetahuan sangat didukung. Hasil penelitian ini mendukung Theory of Planned Behavior yang menyatakan bahwa dukungan organisasi merupakan faktor dari norma subjektif

\section{Attitude toward behavior dan Perilaku Berbagi Pengetahuan Akuntansi}

Hipotesis kelima menyatakan bahwa attitude toward behavior berpengaruh positif terhadap perilaku berbagi pengetahuan akuntansi, secara empiris terbukti didukung. Hasil penelitian mendukung penelitian Jolaee et al. (2013) dan Iqbal et al. (2011), Ajzen (2005) dan Andayani (2016) yang menemukan bahwa attitude toward behavior berpengaruh positif terhadap perilaku berbagi pengetahuan. Jolaee et al. (2013) seseorang yang memiliki sikap positif terhadap berbagi pengetahuan maka akan cenderung untuk melakukan suatu perilaku tersebut.

Hasil penelitian ini mendukung Theory of Planned Behavior yang menyatakan bahwa attitude toward behavior merupakan salah satu faktor pembentuk dari niat untuk melakukan suatu perilaku.

\section{Norma Subjektif dan Perilaku Berbagi Pengetahuan Akuntansi}

Hipotesis keenam menyatakan bahwa norma subjektif berpengaruh positif terhadap perilaku berbagi pengetahuan akuntansi secara empiris terbukti didukung. Hasil pengujian ini menunjukkan bahwa individu mendapatkan dukungan dari

keluarga dan rekan kerja yang menginginkannya untuk berbagi pengetahuan, mendorong rekan kerja lain untuk ikut serta berbagi pengetahuan, dan menganggap bahwa pengalaman yang didapatkan harus dibagikan. Dengan adanya dukungan dari orang-orang terdekat maka efisiensi kerja di institusi akan dapat tercapai, karena didorong oleh orang-orang terdekat.

Hasil ini mendukung penelitian Penelitian ini mendukung penelitian Iqbal et al. (2011), Ajzen (2005), Andayani (2016) yang menemukan bahwa dukungan dari orang-orang terdekat yang dirasakan berpengaruh positif terhadap perilaku seseorang. Arthur et al. (2008) dalam Iqbal et al. (2011) menjelasakan bahwa norma subjektif merupakan suatu hal yang penting untuk mempengaruhi seseorang untuk berbagi pengetahuan karena dengan adanya dukungan dari orang-orang terdekat dapat membantu dalam meningkatkan sebuah organisasi atau institusi dalam melakukan suatu perilaku berbagi pengetahuan.

\section{Perceived Behavior Control dan Perilaku Berbagi Pengetahuan Akuntansi}

Hasil penelitian ini mendukung Theory of Planned Behavior yang menyatakan bahwa kontrol perilaku yang dipersepsikan 
(perceived behavior control) merupakan salah satu faktor pembentuk dari niat untuk melakukan suatu perilaku. Hasil pengujian ini menunjukkan bahwa individu memiliki persepsi kemudahan untuk melakukan suatu perilaku berbagi pengetahuan akuntansi, seperti menganggap berbagi pengetahuan merupakan hal yang mudah dan bisa dilakukan, ketika ada pengalaman yang mendukung kegiatan berbagi pengetahuan dapat dilakukan, dan adanya sarana dan prasarana pendukung, sehingga kegiatan berbagi pengetahuan dilakukan.

Hasil pada hipotesis kedelapan mendukung penelitian Ho et al, (2011), Andayani (2016), Ajzen (2005) yang menemukan bahwa perceived behavior control berpengaruh positif terhadap perilaku seseorang. Perceived behavior control mengacu pada persepsi kemudahan atau kesulitan melakukan perilaku dan

diasumsikan untuk mencerminkan pengalaman masa lalu serta antisipasi terhadap hambatan dan rintangan (Ajzen, 1991).

\section{Simpulan dan Saran}

Berdasarkan pada hasil pembahasan maka dapat disimpulkan sebagai berikut.

1) Self efficacy berpengaruh positif terhadap attitude toward behavior

berbagi pengetahuan akuntansi. Semakin tinggi self efficacy yang dimiliki semakin tinggi juga sikap berbagi pengetahuan akuntansi.

2) Jaringan sosial terbukti berpengaruh positif terhadap attitude toward behavior berbagi pengetahuan akuntansi. Hal ini berarti semakin tinggi jaringan sosial yang dimiliki maka semakin tinggi juga sikap berbagi pengetahuan akuntansi.

3) Extrinsic reward terbukti berpengaruh positif terhadap attitude toward behavior berbagi pengetahuan akuntansi. Semakin tinggi extrinsic reward yang didapatkan maka semakin tinggi juga sikap berbagi pengetahuan akuntansi.
4) Dukungan organisasi terbukti berpengaruh positif terhadap norma subjektif. Semakin baik dukungan organisasi yang dalam hal ini institusi tempat dosen bekerja maka semakin tinggi pula norma subjektif untuk melakukan suatu perilaku berbagi pengetahuan akuntansi.

5) Attitude toward behavior terbukti berpengaruh positif terhadap perilaku berbagi pengetahuan akuntansi. Semakin tinggi sikap mereka terhadap suatu perilaku maka semakin tinggi juga perilaku yang akan ditampilkan.

6) Norma subjektif terbukti berpengaruh positif terhadap perilaku berbagi pengetahuan akuntansi. Semakin tinggi dukungan orang-orang terdekat untuk melakukan suatu perilaku semakin tinggi juga perilaku yang akan ditampilkan.

7) Perceived behavior control terbukti berpengaruh positif terhadap perilaku berbagi pengetahuan akuntansi. Semakin tinggi persepsi kemudahan dan sedikit kendala, semakin tinggi juga perilaku yang akan ditampilkan.

Hasil penelitian ini berimplikasi pada pengembangan akuntansi keperilakuan, yang mana dalam penelitian ini faktor dari Theory of Planned Behavior (TPB) dan hasil penelitian ini memiliki pengaruh langsung pada responden, hal ini membuktikan bahwa kegiatan berbagi pengetahuan berjalan dengan baik jika individu memiliki suatu keyakinan terhadap kemampuannya, mendapatkan fasilitas, memiliki dukungan dari institusi, mendapatkan dukungan dari orang-orang terdekat, dan memiliki suatu pengalaman, maka suatu perilaku berbagi pengetahuan tersebut akan ditampilkan.

Penelitian ini masih memiliki beberapa keterbatasan, adapun keterbatasan penelitian ini adalah sampel yang didapat hanya sedikit, karena terbatas pada dosen akuntansi yang aktif bekerja di perguruan tinggi negeri maupun swasta. Berdasarkan keterbatasan dalam penelitian ini, maka 
untuk penelitian selanjutnya dapat mempertimbangkan bahwa teknik yang digunakan tidak hanya kuesioner tetapi juga wawancara dan lainnya. Selain itu penelitian ini hendaknya menggunakan media internet untuk penyebaran kuesioner seperti kuesioner online, pengiriman via email atau facebook sehingga responden lebih banyak didapatkan.

\section{Daftar Rujukan}

Abdillah, Willy dan Jogiyanto. 2015. Partial Least Square (PLS) - Alternatif Structural Equation Modeling (SEM) dalam Penelitian Bisnis. Yogyakarta: CV. Andi Offset.

Achmat, Zakarija. 2010. Theory of Planned Behavior, Masihkah Relevan?. http://zakarija.staff.ummac.id 7

Desember 2016 (19:15)

Ajzen, I. and M. Fishbein. 1975. Belief, Attitude, Intention and Behaviour: An introduction to Theory and Research. California: Addison-Wesley.

Ajzen, I. 1991. The Theory of Planned Behavior. Organizational Behavior and Human Decision Processes, 50 (2), 179-211.

Ajzen, I. 1980. Understanding Attitudes and Predicting Social Behavior. Englewoods Cliffs, NJ: Prentice Hall.

Ajzen, I. 2005. Attitudes, Personality, and Behavior. Second Edition. England: Open University Press.

Ajzen, I. 2006. Constructing a TPB questionnaire: Conceptual and methodological considerations, Retrieved March 22, 2007, from http://www.people.mass.edu/aizen/tpb. $\underline{\mathrm{html}}$.

Andayani, Seprizah. 2016. Faktor-Faktor Yang Mempengaruhi Accounting
Knowledge Sharing Intention Melalui Internet Pada Mahasiswa Akuntansi. Universitas Bengkulu.

Bandura, A. 1997. Self-efficacy: The exercise of control. New York: W. H. Freeman and Company.

Baron, R. A., \& Byrne, D. 2000. Social psychology (9 th edition). Massachusetts: Allyn \& Bacon.

Bock, G. W., Zmud, R.W., Kim Y. G., and Lee, J. N. 2005. Behavioral Intention in Knowledge sharing: Examining the Roles of Extrinsic Motivation, Socialpsychological Forces, and Organizational Climate. MIS Quarterly, 29 (1), 87-111.

Chin, W. W. 1998. The Partial Least Squares Approach to Structural Equation Modeling. In G. A. Marcoulides (Ed.). Modern Methods for Business Research (295-336). Mahwah, New Jersey, London: Lawrence Eribaum Associates.

Cooper, Donald R., and Schindler, Pamela S. 2012. Business Research Methods, 12th ed. New York: McGraw-Hill.

Damsar, 2002. Pengantar Sosiologi Ekonomi. Jakarta: PT. Raja Grafindo Persada.

Eisenberger, R., Huntington, R., Hutchison, S., \& Sowa, D. 1986. Perceived Organizational Support. Journal of Applied Psychology, Vol 77: 642-655.

Fornell, C. and Larcker, D.F. 1981. Evaluating Structural Equation Models with Unobservable Variables and Measurement Error. Journal of Marketing Research. 18 (1), 39-50.

Ghazali, G. 2006. Structural Equation Modeling: Metode Alternatif dengan Partial Least Square. Semarang: Badan 
Penerbit Universitas Diponegoro.

Gibson, James L, John M Ivancevich, and James H Donnely. 1991. Organisasi, Perilaku, Struktur dan Proses, Terjemahan. Edisi Empat, Erlangga. Jakarta.

Ghozali, Imam. 2014. Structural Equation Modeling Metode Alternatif dengan Partial Least Square. Edisi 4. Semarang: Badan Penerbit Universitas Diponegoro.

Ho, S.C., Ting P.H., Bau, D.Y., and Wei, C.C. 2011. Knowledge-Sharing Intention in Virtual Community: A Study of Participants in the Chinese Wikipedia. Cyberpsychology, Behavior, and Social Networking, 14

(9), 541-545.

Indra, Muhammad Ibnu Sina. 2014. Pengaruh Dukungan Organisasi Terhadap Perilaku Berbagi Pengetahuan Di Mediasi Oleh Kepercayaan Organisasi Dan Komitmen Organisasi. Jurnal Ilmu Manajemen. Vol. 2 No. 2. April 2014 Universitas Negeri Surabaya.

Iqbal, Muhammad Jawad., Rasli, Amran., Heng, Low Hock., Mohamad., Hassan, Ibne., Jolaee, Ali. 2011. Academic staff knowledge sharing intentions and university innovation capability. African Journal of Business Management. Vol. 5 (37), pp. 1105111059, 9 Nov 2011.

Ismail WKW, Nor KM, and Marjani T. 2009. The Role of Knowledge Sharing Practice in Enhancing Project Success. Journal Contemporary Research In Business, 1, 34-52.

Ivancevich, Konopaske, dan Matteson. 2006. Perilaku dan Manajemen Organisasi. Jakarta: PT. Erlangga.
Lin, Hsiu-Fen. 2007. Effect of Extrinsic and Intrinsic Motivation on Employee Knowledge Sharing Intentions. Journal of Information Science, 33 (2), 135149.

Jolaee, Ali., Nor, Khalil Md., Khani, Naser., Yusoff, dan Rosman Md. 2013. Factors affecting knowledge sharing intention among academic staff. International Journal of Educational Management. 2014, Vol. 28 No. 4 pp. 413-431.

Kidwell, J. J., Linde, K. M. V., dan Johnson, S. L. 2000 . Applying corporate knowledge management practices in higher education. Educase Quarterly, 3(4), 28-33.

Kreitner, Robert dan Kinicki, Angelo. 2005.

Perilaku Organisasi, buku 1 dan 2. Jakarta: Salemba Empat.

Lawang, Robert M. Z. 2005. Kapital Sosial dalam Perspektif Sosiologik. Cetakan Kedua. FISIP UI Press. Depok.

M. Iqbal Hasan. 2001. Pokok-pokok Materi Statistik I (Statistik Deskriptif), Bumi Aksara. Jakarta.

Malhotra, N.K. and Birks, D.F. 2007. Marketing Research: An Apllied Approach. 3rd European Edition. Harlow, UK: Pearson Education.

Mahyarni, 2013. Theory of Reasoned Action dan Theory of Planned Behavior (Sebuah Kajian Historis tentang Perilaku). http://ejournal.uinsuska.ac.id/index.php/elriyasah/article/ view/17/13 11 Desember 2016 (15:43)

Randal, M. L., Bormann, C. A., \& Birjulin, A., 1999. Organization Politics and Organizational Support as a Predictor of Work Attitudes, Job Performance, 
and Organizational Citizenship Behavior. Journal of Organizational Behavior, Vol. 18: 159-180.

Robins, Stephen P. 2001. Organizational Behaviour, New Jersey: Prentice Hall International Inc.

Saad, A., dan Haron, H. 2013. A Case Study Of Academics Knowledge Sharing Motivations at Malaysian Public Academic Institutions. Journal of Education and Vocational Research, 4(9): 265-274.

Sekaran, Uma. 2006. Metodologi Penelitian untuk Bisnis Buku 1 dan 2 Edisi Pertama. Jakarta: Salemba Empat.

Sarwono, Jonathan. 2006. Metode Penelitian Kuantitatif dan Kualitatif. Yogyakarta: Graha Ilmu.

Sarwono, Jonathan. 2007. Analisis Jalur Untuk Riset Bisnis: Aplikasi RisetPemasaran, Keuangan, MSDM dan Kewirausahaan. Yogyakarta: PenerbitAndi.

Sugiyono. 2012. Metode Penelitian Administrasi. Cetakan Ke-20. Bandung: Alfabeta.

Vaughan, G.M., \& Hogg, M.A.(2005). Introduction to social psychology (ed. 4). Australia : Pearson Prentice Hall

Yamin, S. dan Kurniawan, H. 2009. Structural Equation Modeling: Belajar Lebih Mudah Teknik Analisis Data Kuesioner dengan LISREL-PLS, Buku

Seri Kedua. Jakarta: Salemba Infotek 